\title{
Isparta ili merkez ilçesinde domates seralarından toplanan Tetranychus urticae Koch (Acari: Tetranychidae) popülasyonlarının bazı akarisitlere karşı direnç düzeyleri ve detoksifikasyon enzimleri ${ }^{1}$
}

\author{
Resistance levels and detoxification enzymes against some acaricides in populations of \\ Tetranychus urticae Koch (Acari:Tetranychidae) collected from tomato greenhouses in \\ central district of Isparta province
}

\author{
Sibel YORULMAZ SALMAN²*
}

Bengi Kevser KAPLAN ${ }^{2}$

\section{Summary}

In this study, the resistance levels of Tetranychus urticae Koch (Acari:Tetranychidae) populations collected from the greenhouses in the central district of the province of Isparta, Deregumu village, in 2014 against abamectin, spiromesifen and hexythiazox were determined by bioassay and biochemical methods. LC $_{50}$ values of $T$. urticae populations were found through leaf disk method by using spray tower. The resistance levels of $T$. urticae populations was determined as between 8.36-25.26 folds against abamectine, 8.16-22.82 folds against spiromesifen and 8.8511.76 folds against hexythiazox. Enzymes of glutathione S-transferase (GST) and monooxygenase (P450) in the $T$. urticae popluations were determined by using the kinetic method; and the enzyme of esterase was determined by using the electrophoresis and kinetic methods. The levels of esterase, glutathione S-transferase (GST), and monooxygenases (P450) in the populations of $T$. urticae were 10.80-22.60, 2.56-2.78 and 0.0020-0.0040 mOD min ${ }^{-1}$ $\mathrm{mg}^{-1}$ protein, respectively. As a result, it was concluded that the esterase and P450 enzymes can be effective, but GST enzyme is not effective in the development of resistance against three acaricides in Tetranychus urticae populations collected from tomato greenhouses.

Key words: Tetranychus urticae, acaricides, resistance, detoxification enzymes

\section{Özet}

Bu çalışmada, Isparta ili Merkez ilçe Deregümü köyü domates seralarından 2014 yılında toplanan T. urticae popülasyonlarının abamectin, spiromesifen ve hexythiazox'a karşı direnç düzeyler bioassay ve biyokimyasal yöntemlerle belirlenmiştir. $T$. urticae popülasyonlarının $L C_{50}$ değeri ilaçlama kulesi kullanılarak yaprak disk metodu ile bulunmuştur. T. urticae popülasyonlarında abamectine'e karşı 8.36-25.26 kat; spiromesifen'e karşı 8.16-22.82 kat ve hexythiazox'a karşı 8.85- 11.76 kat arasında direnç düzeyleri belirlenmiştir. $T$. urticae popülasyonlarında dirençle bağlantılı detoksifikasyon enzimlerinden esteraz enzimi elektroforez ve kinetik yöntemlerle, GST ve P450 enzimleri ise kinetik yöntemle belirlenmiştir. T. urticae popülasyonlarının esteraz, GST ve P450 seviyeleri sırasıyla 10.80-22.60, 2.56-2.78 ve 0.0020-0.0040 mOD min ${ }^{-1} \mathrm{mg}^{-1}$ protein arasında değişmiştir. Sonuç olarak domates seralarından toplanan $T$. urticae popülasyonlarında üç akarisite karşı gelişen dirençte esteraz ve P450 enzimlerinin etkili olabileceği, ancak GST enziminin ise direnç gelişiminde etkili olmadığı görüşüne varılmıştır.

Anahtar sözcükler: Akarisit, detoksifikasyon enzimleri, direnç, Tetranychus urticae

\footnotetext{
${ }^{1}$ Bu çalışma TÜBITAK 2209-A Üniversite Öğrencileri Yurt İçi Araştırma Projeleri Destek Programı tarafından desteklenmiştir.

${ }^{2}$ Süleyman Demirel Üniversitesi, Ziraat Fakültesi, Bitki Koruma Bölümü, Isparta

*Sorumlu yazar (Corresponding author) e-mail: sibelyorulmaz@sdu.edu.tr

Alını̧̧ (Received): 23.10.2014 Kabul ediliş (Accepted): 01.12.2014
} 


\section{Giriş}

İki noktalı kırmızı̈rümcek, Tetranychus urticae Koch (Acari: Tetranychidae) dünyada birçok kültür bitkisi çeşidinde ekonomik kayıplara neden olan önemli bir zararlıdır (Helle \& Sabelis, 1985). T. urticae'nin dünyada 150'den fazlası ekonomik öneme sahip, yaklaşık 1200 bitkide zarar yaptığı belirlenmiştir (Zhang, 2003). İki noktalı kırmızıörümcek bitki özsuyunu sokup emme suretiyle yapraklarda sararma, kuruma ve dökülmeyle doğrudan zarar yaparken, fotosentezin azalması ve virüs hastalıklarının nakliyle de dolaylı zarar meydana getirmektedir (Jeppson et al., 1975). T. urticae'nin savaşımında, uygulamasının kolay olması ve kısa sürede etki göstermesi nedeniyle kimyasal mücadele ilk sırada tercih edilmektedir (Van Leeuwen et al., 2005). Ancak T. urticae'nin fitofag yapısı, üreme potansiyelinin yüksek ve yaşam döngüsünün kısa olması gibi faktörler birkaç uygulamadan sonra akarisitlere direnç geliştirmesini kolaylaştırmaktadır (Stumpf \& Nauen, 2001; Van Leeuwen et al., 2006). T. urticae'nin dünyada 60 ülkede 80'den fazla akarisite karşı direnç geliştirdiği belirlenmiştir (Miresmailli et al., 2006).

Son yıllarda Isparta İli Merkez ilçe Deregümü köyünde seracılık faaliyetleri oldukça yoğun bir şekilde yapılmaktadır. Antalya ilinde özellikle yaz aylarını içinde bulunduran dönemin sıcaklık ve nem değerlerinin aşırı yükselmesi nedeniyle örtüaltı üretim için alternatif bölgeler aranmıştır. Son beş yıllık süreç içerisinde Akdeniz Bölgesi'nde yer almasına rağmen, karasal iklim özelliği gösteren ve batı geçit kuşağında yer alan Isparta ili domates ve kesme çiçek örtüaltı üretimde önemli bir yere gelmiştir. Isparta İ Gıda, Tarım ve Hayvancılık Müdürlüğü 2012 yıl verilerine göre Merkez İlçe Deregümü Köyü'nde 480 dekarlık alan üzerinde örtüaltı domates üretimi yapılmış ve 4451 ton domates ürünü elde dilmiştir (Anonymous, 2012). Deregümü köyü domates üretimi seraları içerisinde en fazla ürün kaybına domates güvesi (Tuta absoluta Meyrick (Lepidoptera: Gelechiidae) ve iki noktalı kırmızı̈rümcek (T. urticae yol açmaktadır. Bu bölgedeki üreticiler hastalık ve zararılarla üretim sezonu boyunca özellikle kimyasal mücadele yapmaktadırlar. Domates seraları içerisinde yoğun uygulanan ilaçlama programı sonucunda zararlıların, özellikle de kırmızı̈rümceklerin kullanılan akarisitlere karşı direnç geliştirmelerinin olası bir durum olduğu düşünülmektedir.

Abamectin (avermectin B1) toprak aktinomiseti Streptomyces avermitilis'den elde edilmiş ve insektisidal, nematisidal ve akarisidal etki gösteren bir pestisittir (Putter et al., 1981; Wang \& Wu, 2007). Abamectin Türkiye'de 1981 yılında ruhsat almış ve birçok kültür bitkisinde zarar yapan T. urticae'nin kontrolünde kullanılmaktadır (Ay et al., 2005). Spiromesifen zararlı kırmızı̈rümcek mücadelesinde kullanılan büyüme düzenleyici bir akarisittir (Nauen et al., 2000; Bretschneider et al., 2007). Tetronik asit türevi grubu içerisinde yer alan spiromesifen zararlılarda lipid sentezini engelleyerek etki göstermekte ve yumurta, larva ve nimf gibi ergin öncesi dönemlerde kullanılmaktadır (Dekeyser, 2005). Hexythiazox Thiazolidine grubu içerisinde yer alan kontakt etkili ve sistemik olmayan bir akarisittir. Hexythiazox kırmızı̈rümceklerde ergin öncesi dönemlerde kullanılmaktadır (Sanatgar et al., 2011). Bu akarisit Entegre Mücadele programları içerisinde kırmızıörümcek mücadelesinde kullanılabilmektedir (Yamamoto et al., 1996).

Bu çalışmada domates seralarından toplanan $T$. urticae popülasyonlarının abamectin, hexythiazox ve spiromesifen akarisitlerine karşı duyarlılık düzeyleri belirlenmiştir. Ayrıca $T$. urticae popülasyonlarında direnç ile bağlantılı olan esteraz, glutation S-transferaz (GST) ve P450 sitokrom monoksigenaz detoksifikasyon enzim düzeyleri de araştırılmıştır. 


\section{Materyal ve Yöntem}

\section{Tetranychus urticae popülasyonlarının orijini ve yetiştirilmesi}

Çalışmada ana materyal olarak kullanılan T. urticae popülasyonları Isparta İli Merkez ilçe Deregümü Köyü'nde bulunan domates seralarından toplanmıştır. Domates seralarına 2014 yılı HaziranTemmuz-Ağustos aylarında survey çalışmaları yapılmış ve 6 adet popülasyon toplanmıştır. Buz kutusu içerisinde laboratuvara getirilen yaprak örnekleri $T$. urticae popülasyonlarının artmasını sağlamak amacıyla temiz barbunya bitkilerine aktarılmıştır. Örnek popülasyonların toplanma yerleri ve toplanma tarihleri çizelge 1'de verilmiştir. Karşılaştırma popülasyonu olarak kullanılan $T$. urticae'nin hassas popülasyonu German Susceptible Strain (GSS) 2001 yılında Süleyman Demirel Üniversitesi, Ziraat Fakültesi, Bitki Koruma Bölümündeki böcek yetiştirme kabinlerine Rothamsted Araştırma İstasyonundan (İngiltere) getirtilmiştir. T. urticae'nin hassas popülasyonuna herhangi bir pestisit uygulaması yapılmadan yetiştirimiştir. Popülasyonlar $26 \pm 1{ }^{\circ} \mathrm{C}$ sıcaklıkta, \% 50-60 orantılı nem ve florasan lambalar ile 16 saat aydınlık, 8 saat karanlık koşullarda kültüre alınmıştır.

Çizelge 1. Denemede kullanılan Tetranychus urticae popülasyonlarının toplanma yerleri ve tarihleri

\begin{tabular}{lll}
\hline Popülasyon adı & Toplandığı yer & Toplandığı tarih \\
\hline ID1 & Domates serası & $15-06-2014$ \\
ID2 & Domates serası & $15-06-2014$ \\
ID3 & Domates serası & $21-07-2014$ \\
ID4 & Domates serası & $21-07-2014$ \\
ID5 & Domates serası & $17-08-2014$ \\
ID6 & Domates serası & $17-08-2014$ \\
Hassas poülasyon (GSS) & - & $21-04-2001$ \\
\hline
\end{tabular}

\section{Akarisitler}

Çalışmada kullanılan akarisitler Isparta İ Gıda, Tarım ve Hayvancılık Müdürlüğü ile yapılan çalışmalar sonucu belirlenmiş olup Isparta İli Merkez İlçe Deregümü Köyü domates seralarında kırmızı̈rümcek mücadelesinde yaygın olarak kullanılan üç akarisit çalışmalarda kullanılmak üzere seçilmiştir. Toksisite çalışmalarında abamectin (Agrimec EC, Syngenta, Japonya), spiromesifen (Oberon SC 240, Bayer Crop Science, Almanya) ve hexythiazox (Twister 5 EC, Hektaş, Türkiye) etkili maddeye sahip akarisitler kullanılmıştır.

\section{Toksisite Testi}

Abamectin, spiromesifen ve hexythiazox'un kırmızı̈rümceklerin ergin öncesi döneminde kullanılması sebebiyle bioassay çalışmaların tamamında 0-24 saatlik $T$. urticae larvaları kullanılmıştır. Aynı dönem kırmızıörümcek larvalarını elde etmek amacıyla, tabanı ıslatılmış pamukla kaplı $9 \mathrm{~cm}$ çapındaki Petri kapları üzerinde hazırlanan barbunya yaprak diskleri üzerine 15 adet ergin $T$. urticae dişisi aktarıımış ve yumurta bırakmaları sağlanmıştır. Yumurtalar açıldıktan sonra aynı dönemdeki akar larvaları denemelerde kullanılmıştır. Bu yöntemde seçilen akarisitler saf su içinde çözdürülerek uygun dozlar hazırlanmıştır. Çalışmada kullanılan akaristlerin ilk dozu olarak tarla uygulama dozlarının iki katı uygulanmıştır. Akarisitlerin tarla uygulama dozlarının iki katlarının kullanılmasının sebebi ise $T$. urticae popülasyonlarının sera koşullarında yoğun pestisit uygulamalarından dolayı bir miktar direnç kazanmış olabileceklerinin düşünülmesinden kaynaklanmaktadır. Hazırlanan ilk dozdan itibaren akarisit konsantrasyonları \%50 seyreltilerek denemeler 1 kontrol+7 doz, 3 tekerrür olacak şekilde kurulmuştur. Nem sağlamak amacıyla tabanı ıslatılmış pamukla kaplı $9 \mathrm{~cm}$ çapındaki Petriler üzerinde $3 \mathrm{~cm}$ 'lik yaprak diskleri hazırlanmıştır. Yaprak diskleri üzerine 25 adet 0-24 saatlik akar larvaları binoküler altında yumuşak uçlu fırça yardımıyla aktarıımıştır. Hazırlanan ilaç konsantrasyonları Petrilere ilaçlama kulesinde $1 \mathrm{~atm}$ basınç altında yaprak üzerine $2 \mathrm{ml}$ olacak şekilde püskürtülmüştür. Kontrol grubuna sadece saf su uygulanmıştır. Kırmızıörümceklerde ölü-canlı sayımları 7. günde yapılmıştır. Elde edilen verilerden yararlanarak farklı akar popülasyonlarının $\mathrm{LC}_{50}$ değerleri POLO bilgisayar paket programında (LeOra Software, 1994) hesaplanmıştır. Direnç katları, araziden alınan $T$. urticae popülasyonlarının LC $_{50}$ değerlerinin hassas popülasyonun $\mathrm{LC}_{50}$ değerine bölünmesi ile hesaplanmıştır. 


\section{Poliakrilamid jel elektroforez (PAGE) ile esteraz enziminin incelenmesi}

Elektroforez çalışmalarında Goka \& Takafuji (1992), Ay \& Gürkan (2005)'ın yöntemleri uyarlanarak kullanılmıştır. Elektroforez işlemi mini kasetli sistemde (Bio-Rad) \%7.5'luk ayırıcı ve \%3.5'luk yükleyici jel içeren kesikli doğal elektroforez metodu kullanılmıştır. Beş adet ergin dişi birey 50 $\mu$ homojenizasyon tamponu (\%0.1 Triton X-100 içeren \%32'lik sukroz) içerisinde plastik ezici ile homojenize edilmiştir. Polimerizasyondan sonra her bir jel hücresine $10 \mu$ l homojenat yüklenmiştir. Elektroforezde koşturma işlemi $150 \mathrm{~V}$ 'da yaklaşık 1.5 saat'de yapılmıştır. $0.2 \mathrm{M}$ fosfat buffer (pH 6.5 ve $\% 1$ aseton içeriyor) ile \%0.02 lik $\alpha$-naphthyl asetat subsrat solüsyonu hazırlanmıştır. Jel bu çözeltide esteraz enzimi inkübasyonu için $30 \mathrm{dk}$ bekletilmiştir. \%0.02'lik $\alpha$-naphthyl asetat solüsyonu ile $\% 0.4$ oranında fast blue BB salt boya solüsyonu hazırlanmış ve jel bu çözeltide 1 saat boyanmıştır. Boyama işlemi bittikten sonra jel \%7'lik asetik asit çözeltisi içerisine alınarak 24 saat sonra görüntüleme cihazında fotoğrafı çekilmiştir.

Tetranychus urticae populasyonlarının esteraz, glutathion S-transferaz (GST) ve monooksigenaz (P450) enzimlerinin kinetik olarak belirlenmesi

Esteraz aktivitesinin kinetik olarak belirlenmesinde substrat olarak a-naphtyl acetate ve Stumpf \& Nauen (2002)'in geliştirdikleri yöntem kullanılmıştır. 20 adet ergin dişi $100 \mu$ l sodyum fosfat buffer $(0.1 \mathrm{M}$, $\mathrm{pH}$ 7.5) (\%0.1 Triton X-100 içeren) içinde homojenize edilmiştir. Bu homojenat $10000 \mathrm{~g},+4{ }^{\circ} \mathrm{C}$ 'de ve $5 \mathrm{dk}$ santrifüj edildikten sonra enzim kaynağı olarak kullanıımıştır. Enzim kaynağı olarak kullanılan supernatant 10 kat seyreltilmiştir. Mikroplakanın hücrelerine $25 \mu$ l supernatant $+25 \mu l$ fosfat buffer $(0.2 \mathrm{M}, \mathrm{pH}: 6)$ konulmuştur. Çalışma hücrelere $200 \mu \mathrm{l}$ substrat solüsyonunun eklenmesiyle başlatılmıştır. Substrat solüsyonu $30 \mathrm{mg}$ fast blue RR tuzunun $50 \mathrm{ml} 0.2 \mathrm{M}$ sodyum fosfat buffer'da çözülmesi ve bu karışıma $500 \mu \mathrm{l} 100 \mathrm{Mm} \alpha$ - naphtyl acetate'ın eklenmesiyle elde edilmiştir. Enzim aktivitesi $23^{\circ} \mathrm{C}, 450 \mathrm{~nm}$ 'de $10 \mathrm{dk}$ süreyle okunmuştur.

GST enziminin kinetik olarak belirlenmesinde Stumpf \& Nauen (2002)'in geliştirdikleri yöntem kullanılmıştır. 30 ergin dişi $300 \mu \mathrm{l}$ Tris $\mathrm{HCL}$ buffer $(0.05 \mathrm{M}, \mathrm{pH}: 7.5)$ içinde homojenize edilmiştir. Supernatant $10000 \mathrm{~g},+4{ }^{\circ} \mathrm{C}$ 'de $5 \mathrm{dk}$ santrifüj edilmiştir. $100 \mu \mathrm{l}$ supernatant, $100 \mu \mathrm{l}$ 1-chloro-2,4dinitrobenzene (CDNB) ve $100 \mu \mathrm{l}$ reduced glutathione (GSH)'dan oluşan toplam hacim mikroplaka hücrelerine konulmuştur. CDNB \%0.1 ethanolde hazırlanmış ve final konsantrasyonda hücrelerde $0.4 \mathrm{mM}$ CDNB bulunmuştur. Absorbanstaki değişim $340 \mathrm{~nm}, 25^{\circ} \mathrm{C}$ 'de ve $5 \mathrm{dk}$ 'da okunmuştur.

Sitokrom P450 monooksigenaz enziminin belirlenmesinde substrat olarak $p$-nitroanisole (PNOD) ve Rose et al. (1995) yöntemi uyarlanarak kullanımıştır. 50 adet dişi birey $100 \mu$ homojenizasyon tampon çözeltisinde (0.05 M Tris- $\mathrm{HCl}+\% 1.15 \mathrm{KCl}+1 \mathrm{mM}$ EDTA pH (7.7)) plastik ezici ile ezilerek $+4{ }^{\circ} \mathrm{C} 10000$ g'de $20 \mathrm{dk}$ santrifüj edilmiştir. Mikroplaka hücrelerine $45 \mu \mathrm{L}$ homojenizasyon buffer $+45 \mu \mathrm{L}$ supernatant $+100 \mu \mathrm{L} 2 \mathrm{mM}$ PNOD eklenerek karışım $30{ }^{\circ} \mathrm{C}$ 'de $5 \mathrm{dk}$ inkübe edilmiştir. Reaksiyon mikroplaka hücrelerine $10 \mu \mathrm{L} 9.6 \mathrm{mM}$ NADPH eklenerek başlatılmıştır. P450 enzim aktivitesi Versamax kinetic mikroplaka okuyucuda $405 \mathrm{~nm}, 30^{\circ} \mathrm{C}$ 'de $15 \mathrm{dk}$ süreyle ölçülmüştür.

Biyokimyasal çalışmalarda, kontrol hücreleri ise homojenatsız olarak okunmuştur. Enzim okumaları dört tekerrürlü olarak yapılmıştır. Tüm enzim aktiviteleri Softmax PRO software programında analiz edilerek sonuçlar mOD $\mathrm{min}^{-1} \mathrm{mg}^{-1}$ protein olarak verilmiştir. Örneklerin toplam protein miktarlarının belirlenmesinde Bradford (1976)'un total protein tayin yöntemi kullanılmış ve Bovine Serum Albumine (BSA) standart olarak alınmıştır. Enzim sonuçlarından elde edilen veriler tek yönlü varyans analizi tekniği ile (One-Way ANOVA) analiz edilmiş ve popülasyonlar arasındaki farklılıkların belirlenmesinde Tukey testi kullanılmıştır (Winer et al., 1991). 


\section{Araştırma Sonuçları ve Tartışma}

\section{Toksisite sonuçları}

Domates seralarından toplanan T. urticae popülasyonları ve hassas popülasyonda abamectin'e karşı belirlenen LC $_{50}$ değerleri ve direnç oranları Çizelge 2'de verilmiştir. $T$. urticae popülasyonlarında abamectin'e karşı belirlenen direnç oarnları 8.21-25.26 kat arasında değişmektedir. Abamectin'e karşı en yüksek direnç oranı ID4 (25.26 kat) popülasyonunda belirlenirken en düşük direnç oranı ise ID6 (8.21 kat) popülasyonunda belirlenmiştir. Sato et al. (2005) $T$. urticae popülasyonunda beş seleksiyon sonucunda 342 kat abamectin direnci geliştiğini bildirmişlerdir. Yorulmaz \& Ay (2009), laboratuvar koşullarında 15 kez selekte ettikleri $T$. urticae popülasyonunda 35.05 kat abamectin direnci belirlemişlerdir.

Çizelge 2. Tetranychus urticae popülasyonlarının abamectin'e karşı belirlenen $\mathrm{LC}_{50}$ değerleri ve direnç oranları

\begin{tabular}{lllll}
\hline Popülasyon & $\mathrm{n}^{*}$ & Eğim \pm se & $\begin{array}{l}\mathrm{LC}(\mathrm{mg} \mathrm{a.i} \\
(95 \% \mathrm{CL})\end{array}$ & $\mathrm{R}^{* *}$ \\
\hline ID1 & 603 & $1.70 \pm 0.14$ & $1.59(1.27-1.93)$ & 8.36 \\
ID2 & 600 & $1.55 \pm 0.12$ & $3.50(2.66-4.65)$ & 18.42 \\
ID3 & 605 & $1.58 \pm 0.12$ & $2.54(2.06-3.08)$ & 13.36 \\
ID4 & 607 & $1.52 \pm 0.13$ & $4.80(2.67-6.31)$ & 25.26 \\
ID5 & 602 & $1.66 \pm 0.13$ & $1.81(0.81-3.09)$ & 9.52 \\
ID6 & 605 & $1.40 \pm 0.14$ & $1.56(0.94-2.23)$ & 8.21 \\
Hassas popülasyon & 608 & $1.58 \pm 0.27$ & $0.19(0.01-0.54)$ & -
\end{tabular}

\footnotetext{
*: denemede kullanılan birey sayı

*: hassas popülasyona göre direnç oranı
}

Domates seralarından toplanan T. urticae popülasyonları ve hassas popülasyonda spiromesifen'e karşı belirlenen $\mathrm{LC}_{50}$ değerleri ve direnç oranları Çizelge 3 'de verilmiştir. $T$. urticae popülasyonlarında spiromesifen'e karşı belirlenen direnç oranları abamectin'e benzer şekilde yüksek bulunmuştur. Abamectin ve spiromesifen'e karşı direnç oranlarının yüksek bulunmasının sebebinin özellikle domates üretim seralarında üretim sezonu boyunca yoğun akarisit uygulamalarına bağlı olduğu düşünülmektedir. Çünkü domates seralarından toplanan $T$. urticae'nin tarla popülasyonları sürekli pestisit uygulamasına maruz kalmakta ve direnç geliştirebilmektedir. Spiromesifen'e karşı en yüksek direnç oranı 22.82 kat ile ID4 popülasyonunda belirlenirken en düşük direnç oranı ise 8.16 kat ile ID2 popülasyonunda belirlenmiştir. Pottelberge et al. (2009), 274 kat spirodiclofen dirençli T. urticae popülasyonunda P450 monoksigenaz ve esteraz enzimlerinin direnç gelişiminde rol oynadığını belirlemişlerdir. Demaeght et al. (2013) 680 kat spirodiclofen dirençli T. urticae popülasyonunun aynı grupta yer alan spiromesifen ve spirotetramat akarisitlerine karşı da çapraz direnç geliştirebileceğini bildirmişlerdir. Hu et al. (2010) 90.8 kat spirodiclofen dirençli Panonychus ulmi (Acari:Tetranychidae) popülasyonunda spirotetramat'a karşı çapraz direnç belirlemişlerdir. Spirodiclofen ve spiromesifen etken maddeleri tetronik asit türevi grubu altında yer alan ve etki mekanizmaları benzer akarisitlerdir. Literatürde spirodiclofen'e karşı kırmızıörümceklerde direnç gelişimi ile ilgili fazla sayıda çalışma bulunmasına karşı, spiromesifen ile çalışma sayısı sınırlıdır. Ancak spirodiclofen ve spiromesifen'in etki mekanizmalarının aynı olduğu düşünülürse, kırmızıörümceklerde spiromesifen'e karşı direnç gelişimi de olası bir durumdur. Çalışmamızda da domates seralarından toplanan T. urticae'nin tarla popülasyonlarında spiromesifen kullanımına bağlı olarak orta düzeyde direnç geliştiği görülmektedir.

Domates seralarından toplanan T. urticae popülasyonları ve hassas popülasyonda hexythiazox'a karşı belirlenen $\mathrm{LC}_{50}$ değerleri ve direnç oranları Çizelge 4'de verilmiştir. $T$. urticae popülasyonlarında hexythiazox'a karşı belirlenen direnç oranları abamectin ve spiromesifen'e göre daha düşük bulunmuştur. T. urticae popülasyonlarında hexythiazox'a karşı belirlenen direnç oranları 8.54-11.76 kat arasında 
değişmektedir. Hexythiazox'a karşı en yüksek direnç oranı ID4 (11.76 kat) popülasyonunda belirlenirken en düşük direnç oranı ise ID5 (8.54 kat) popülasyonunda bulunmuştur. Reissig \& Hull (1991) elma bahçelerinden topladıkları $P$. ulmi'nin tarla popülasyonlarında hexythiazox direnci belirlemişlerdir. Pree et al. (2002) hexythiazox dirençli $P$. ulmi popülasyonunda 2000 kat clofentezine direnci belirlemişlerdir. Yorulmaz et al (2010), Isparta elma bahçelerinden topladıkları 13 adet $T$. urticae popülasyonunda cyhexatin'e karşı 1.24-3.36 kat, propargite karşı ise 1.23-3.18 kat arsında değişen direnç tespit etmişlerdir.

Çizelge 3. Tetranychus urticae popülasyonlarının spiromesifen'e karşı belirlenen LC $_{50}$ değerleri ve direnç oranları

\begin{tabular}{ccccc}
\hline Popülasyon & $\mathrm{n}^{*}$ & Eğim \pm se & $\begin{array}{c}\mathrm{LC}_{50}\left(\left.\mathrm{mg} \mathrm{a.i}\right|^{-1}\right) \\
(95 \% \mathrm{CL})\end{array}$ & $\mathrm{R}^{* *}$ \\
\hline ID1 & 600 & $1.37 \pm 0.11$ & $35.16(28.17-43.15)$ & 11.75 \\
ID2 & 602 & $1.28 \pm 0.11$ & $24.40(16.36-33.64)$ & 8.16 \\
ID3 & 603 & $1.57 \pm 0.12$ & $38.90(28.00-52.70)$ & 13.01 \\
ID4 & 608 & $1.49 \pm 0.13$ & $68.25(45.72-103.48)$ & 22.82 \\
ID5 & 603 & $1.56 \pm 0.12$ & $28.94(15.64-43.68)$ & 9.67 \\
ID6 & 600 & $1.90 \pm 0.16$ & $51.26(31.99-76.75)$ & 17.14 \\
Hassas popülasyon & 603 & $1.21 \pm 0.47$ & $2.99(1.51-6.14)$ & -
\end{tabular}

*: denemede kullanılan birey sayı

*: hassas popülasyona gore direnç oranı

Çizelge 4. Tetranychus urticae popülasyonlarının hexythiazox'a karşı belirlenen $\mathrm{LC}_{50}$ değerleri ve direnç oranları

\begin{tabular}{lllll}
\hline Popülasyon & $\mathrm{n}^{*}$ & Eğim \pm se & $\begin{array}{l}\mathrm{LC}_{50}\left(\mathrm{mg} \text { a.i } \mathrm{I}^{-1}\right) \\
(95 \% \mathrm{CL})\end{array}$ & $\mathrm{R}^{* *}$ \\
\hline ID1 & 602 & $1.61 \pm 0.13$ & $14.53(6.67-18.76)$ & 8.85 \\
ID2 & 602 & $1.43 \pm 0.12$ & $16.40(9.55-22.62)$ & 10.00 \\
ID3 & 607 & $1.36 \pm 0.12$ & $16.07(13.55-20.30)$ & 9.79 \\
ID4 & 610 & $1.33 \pm 0.11$ & $19.29(15.22-24.45)$ & 11.76 \\
ID5 & 605 & $1.40 \pm 0.12$ & $14.01(11.28-20.02)$ & 8.54 \\
ID6 & 606 & $1.12 \pm 0.21$ & $15.26(13.40-19.50)$ & 9.30 \\
Hassas popülasyon & 602 & $1.53 \pm 0.16$ & $1.64(0.94-2.42)$ & - \\
\end{tabular}

*: denemede kullanılan birey sayı

hassas popülasyona gore direnç oranı

\section{Sonuçları}

Esteraz, Glutathion S-transferaz (GST) ve Sitokrom P450 Monoksigenaz Enzim Aktivitesi

Tetranychus urticae'nin hassas ve domates seralarından toplanan tarla popülasyonlarının esteraz, GST ve P450 enzim aktivitesi sonuçları Çizelge 5'de verilmiştir. T. urticae popülasyonlarında en yüksek

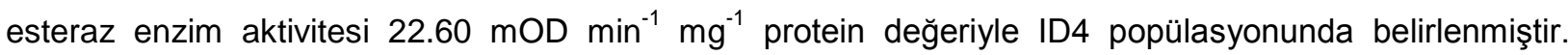
Esteraz enzim aktivitesi bakımından ID4, ID2 ve ID6 popülasyonları istatistiki olarak aynı grup içerisinde yer almıştır $(P<0.05)$. ID2, ID3 ve ID5 popülasyonlarının esteraz enzim seviyeleri hassas popülasyona göre yüksek bulunmuş ve farklı bir istatistik grupla ifade edilmiştir. Domates seralarından toplanan $T$. urticae popülasyonlarının GST enzim aktiviteleri hassas popülasyonla benzer bulunmuş ve aynı istatistik grup içerisinde yer almışlardır $(P<0.05)$. Domates seralarından toplanan $T$. urticae popülasyonlarında en yüksek P450 monoksigenaz enzim aktivitesi $0.0042 \mathrm{mOD} \mathrm{min}^{-1} \mathrm{mg}^{-1}$ protein değeri ile ID4 popülasyonunda, en düşük enzim seviyesi ise $0.0026 \mathrm{mOD} \mathrm{min}^{-1} \mathrm{mg}^{-1}$ protein değeri ile ID1 popülasyonunda belirlenmiştir. P450 enzim aktivitesi bakımından ID2, ID4, ID5 ve ID6 popülasyonları istatistiki olarak aynı grupta yer alırken, ID1 ve ID3 popülasyonları ise farklı bir grubu oluşturmuştur $(P<0.05)$. 
Çizelge 5. Hassas ve domates seralarından toplanan Tetranychus urticae popülasyonlarının esteraz enzim aktiviteleri

\begin{tabular}{|c|c|c|c|}
\hline Popülasyon & $\mathrm{n}^{*}$ & $\begin{array}{l}\text { Spesifik aktivite } \\
\text { mOD } \text { min }^{-1} \mathrm{mg}^{-1} \text { protein }\end{array}$ & $\mathrm{R} / \mathrm{S}^{\star *}$ \\
\hline \multicolumn{4}{|l|}{ Esteraz } \\
\hline Hassas popülasyon & 4 & $10.80 \mathrm{c}^{\star \star \star}$ & \\
\hline ID1 & 4 & $15.25 b$ & 1.41 \\
\hline ID2 & 4 & $20.38 \mathrm{a}$ & 1.88 \\
\hline ID3 & 4 & $17.31 \mathrm{~b}$ & 1.60 \\
\hline ID4 & 4 & $22.60 \mathrm{a}$ & 2.09 \\
\hline ID5 & 4 & $15.36 \mathrm{~b}$ & 1.42 \\
\hline ID6 & 4 & $19.42 \mathrm{a}$ & 1.79 \\
\hline \multicolumn{4}{|l|}{ GST } \\
\hline Hassas popülasyon & 4 & $2.78 \mathrm{a}^{\star \star \star}$ & $<1$ \\
\hline ID1 & 4 & $2.67 \mathrm{a}$ & $<1$ \\
\hline ID2 & 4 & $2.59 \mathrm{a}$ & $<1$ \\
\hline ID3 & 4 & $2.56 \mathrm{a}$ & $<1$ \\
\hline ID4 & 4 & $2.75 \mathrm{a}$ & $<1$ \\
\hline ID5 & 4 & $2.70 \mathrm{a}$ & $<1$ \\
\hline ID6 & 4 & $2.61 \mathrm{a}$ & $<1$ \\
\hline \multicolumn{4}{|l|}{ P450 } \\
\hline Hassas popülasyon & 4 & $0.0020 \mathrm{c}^{\star \star \star}$ & \\
\hline ID1 & 4 & $0.0026 \mathrm{~b}$ & 1.30 \\
\hline ID2 & 4 & $0.0040 \mathrm{a}$ & 2.00 \\
\hline ID3 & 4 & $0.0031 \mathrm{~b}$ & 1.55 \\
\hline ID4 & 4 & $0.0042 \mathrm{a}$ & 2.10 \\
\hline ID5 & 4 & $0.0035 \mathrm{a}$ & 1.75 \\
\hline ID6 & 4 & $0.0038 \mathrm{a}$ & 1.90 \\
\hline
\end{tabular}

* Tekerrür sayısı

** Denenen popülasyonun enzim aktivitesi/ hassas popülasyonun enzim aktivitesi

${ }^{* * * A y n ı ~ h a r f l e r ~ i s t a t i s t i k i ~ o l a r a k ~ a y n ı ~ g r u b u ~ g o ̈ s t e r m e k t e d i r ~}(P<0.05)$

\section{Poliakrilamid jel elektroforez sonuçları}

Tetranychus urticae popülasyonlarının esteraz enzim bantları poliakrilamid jel elektroforez yöntemiyle belirlenmiş ve bantlar şekil 1'de verilmiştir. Ayrıca popülasyonların esteraz bantlarının kantitatif yoğunlukları densiometrede belirlenerek sonuçlar Çizelge 6'da gösterilmiştir.

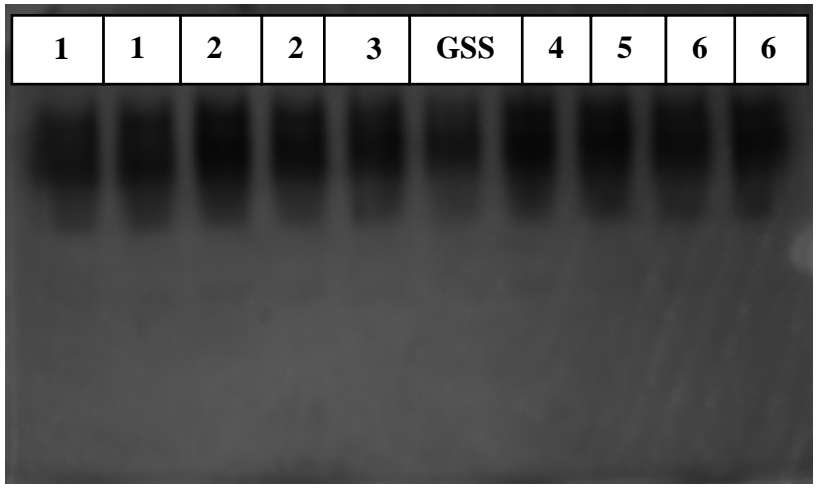

Şekil 1. Tetranychus urticae popülasyonlarının esteraz bantları (1: ID1, 2: ID2, 3: ID3, GSS: hassas popülasyon, 4: ID4, 5: ID5, 6: ID6)

Tetranychus urticae popülasyonlarının esteraz bantları incelendiğinde, domates seralarından toplanan tarla popülasyonlarına ait esteraz bantlarının hassas popülasyona ait esteraz bandına göre daha koyu çıktığı belirlenmiştir. Ayrıca Çizelge 6 incelendiğinde domates seralarından toplanan T. urticae popülasyonlarının esteraz bantlarından belirlenen kantitatif yoğunluklarının hassas popülasyona göre daha yüksek olduğu belirlenmiştir. Bu sonuçlar T. urticae'nin tarla popülasyonlarının esteraz enzimlerinin kinetik olarak belirlenmesi sonucu elde edilen sonuçlar ile uyuşmaktadır. Çünkü tarla popülasyonlarının 
tamamında esteraz enzim aktivitesi hassas popülasyona göre yüksek bulunmuştur. Ayrıca tarla popülasyonlarında abamectin, spiromesifen ve hexythiazox'a karşı belirlenen direnç sonuçları ile de uyum göstermektedir.

Çizelge 6. Tetranychus urticae popülasyonlarının esteraz bantlarının kantitatif yoğunlukları $(P<0.05)^{a}$

\begin{tabular}{lll}
\hline Popülasyon & Toplam yoğunluk \pm SE & Oran $^{\mathrm{b}}$ \\
\hline Hassas popülasyon & $2420.01 \pm 1.19 \mathrm{~B}$ & - \\
ID1 & $2945.00 \pm 1.25 \mathrm{~A}$ & 1.21 \\
ID2 & $3456.05 \pm 1.35 \mathrm{~A}$ & 1.42 \\
ID3 & $3019.04 \pm 1.28 \mathrm{~A}$ & 1.24 \\
ID4 & $4325.08 \pm 1.21 \mathrm{~A}$ & 1.78 \\
ID5 & $3489.03 \pm 1.38 \mathrm{~A}$ & 1.44 \\
ID6 & $3845.02 \pm 1.99 \mathrm{~A}$ & 1.58 \\
\hline
\end{tabular}

${ }^{a}$ Aynı harfler istatistiki olarak aynı grubu göstermektedir $(\mathrm{P}<0.05)$

${ }^{\mathrm{b}}$ Tetranychus urticae popülasyonlarının enxim aktivitesi/hassas popülasyon enzim aktivitesi

Esteraz, GST ve sitokrom P450 enzimleri birçok insektisit ve akarisit detoksifikasyonunda rol oynamaktadır (Konanz \& Nauen 2004). Literatürde T. urticae'de birçok akarisite karşı gelişen dirençte detoksifikasyon enzimlerinin rol oynadığı görülmektedir. Yang et al. (2002), bifenthrin ile selekte edilen $T$. urticae popülasyonunda esteraz seviyesinde artış belirlerken, GST aktivitesinin azaldığını bulmuştur. Stumpf \& Nauen (2002) T. urticae'nin abamectin dirençli tarla popülasyonunda hassas popülasyonla karşıllaştırıldığında, 1.6 kat esteraz ve 12.7 kat P450 enzim aktivitesi belirlemişlerdir. Bu çalışmada da benzer şekilde T. urticae'nin tarla popülasyonlarında abamectin direnci belirlenmiş ve esteraz ve P450 enzim seviyeleri yüksek bulunmuştur. Çalışmamızda özellikle kırmızıörümcek popülasyonlarında en yüksek direnç abamectin'e karşı belirlenmiştir. Rauch \& Nauen (2003), 13 kat spirodiclofen dirençli $T$. urticae'de 1.2 kat esteraz enzim aktivitesi belirlemişlerdir. Çalışmamızda $T$. urticae'nin tarla popülasyonlarında spirodiclofen ile aynı etki mekanizmasına sahip olan spiromesifen'e karşı 8.21-25.26 kat direnç oranı ve esteraz enzim aktivitesi yüksek bulunmuştur. Van Leeuwen \& Tirry (2007), $T$. urticae'nin tarla popülasyonunda yüksek oranda bifenthrin direnci ve esteraz aktivitesi bulmuşlardır. Van Leeuwen \& Tirry (2007), pamuk bitkisinden toplanan T. urticae'nin tarla popülasyonunda yüksek oranda bifenthrin direnci ve esteraz aktivitesi bulmuşlardır. Khajehali et al. (2011) gül üzerinden toplanan ve birçok akarisite karşı duyarlı olan faklı T. urticae popülasyonlarında GST enzim aktivitelerinde önemli bir farklılık belirlememişlerdir. Çalışmamızda da benzer şekilde T. urticae'nin tarla popülasyonlarının GST enzim aktiviteleri ile hassas popülasyonun GST enzim aktivitesi arasında fark bulunmamıştır. Lin et al. (2009), börülce üzerinden topladıkları ve seleksiyon sonucu 8.7 kat abamectin dirençli Tetranychus cinnabarinus (Boiduval) (Acari:Tetranychidae) popülasyonunda 2.7 kat esteraz ve 3.4 kat GST enzim aktivitesi belirlemişlerdir. Ay \& Kara (2011), fasulye bitkisi üzerinde yetiştirilen 105.27 kat clofentezine dirençli $T$. urticae popülasyonunun esteraz bant yoğunluğunun fazla olduğunu belirlemişlerdir. Moghadam et al. (2012), gül bitkisi üzerinden toplanan fenazaquin dirençli $T$. urticae popülasyonlarında hassas popülasyona göre esteraz enziminin arttığını belirlemişlerdir. Literatür bilgileri kırmızıörümceklerde akarisitlere karşı gelişen dirençte detoksifikastyon enzimlerinin etkili olduğunu belirtmektedir. Bu çalışmada T. urticae'nin domates seralarından toplanan tarla popülasyonlarında üç farklı akarisite karşı gelişen dirençte özellikle esteraz ve P450 enzimlerinin rol oynadığını akla getirmektedir. Özellikle her üç akarisite karşı en yüksek oranda direnç belirlenen ID4 popülasyonunda esteraz ve P450 enzim aktivitelerinin diğer popülasyonlara göre en yüksek bulunması da bu görüşü desteklemektedir. Buna karşılık GST enziminin kinetik olarak ölçülmesinde tarla popülasyonları ve hassas popülasyon arasında farklılık belirlenmemiştir. Ancak bu tür çalışmalarda daha detaylı araştırmalar mutlaka yapılmalı ve özellikle pestisitlerin etki mekanizmalarını artıran ve detoksifikasyon enzim inhibitörü olarak görev yapan sinerjist çalışmalarınında yapılması gerekmektedir. 
Sonuç olarak domates seralarından toplanan $T$. urticae popülasyonlarında abamectin, spiromesifen ve hexythiazox akarisitlerine karşı orta düzeyde direnç belirlenmiştir. Bunun yanı sıra $T$. urticae'nin tarla popülasyonlarında bu üç akarisite karşı gelişen dirençte özellikle esteraz ve P450 enzimlerinin rol oynayabileceği buna karşılık GST enziminin ise etkisinin bulunmadığı belirlenmiştir. Dünyada ve ülkemizde iki noktalı kırmızıörümceğin akarisitlere karşı direnç gelişimi ve mekanizmasının belirlendiği çalışma sayısı oldukça fazladır. Ancak Isparta ili Merkez ilçe Deregümü domates seraları üretim açısından yeni bir bölge olması ve yoğun pestisit uygulamalarının yapılmasından dolayı bu alanda $T$. urticae popülasyonlarının direnç gelişimi bakımından incelenmesi gerekliliğini ortaya koymuştur. Bu çalışma sonucunda Isparta ilindeki Merkez ilçe Dergümü köyü domates seralarında kırmızıörümceklere karşı yaygın olarak kullanılan üç akarisitin $T$. urticae popülasyonunlarında önemli bir duyarlılık kaybına neden olduğu bulunmuştur. Bu akarisitleri sık aralıklarla ve arka arkaya kullanmak yerine, farklı etki mekanizmasına sahip akarisitlerin rotasyonla kullanımlarının yararlı olacağı düşünülmektedir. Zararlılarla etkili bir kimyasal mücadele için duyarlılık düzeylerinin belirlenmesi önemlidir. Bu nedenle zararlıların duyarlılık düzeylerinin sık aralıklar kontrol edilerek direncin önlenmesi veya geciktirilmesi için gerekli önlemlerin alınması gerektiği düşünülmektedir.

\section{Teşekkür}

Çalışmayı maddi yönden destekleyen TÜBITAK 2209-A Üniversite Öğrencileri Yurt İçi Araştırma Projeleri Destek Programı'na teşekkür ederiz.

\section{Yararlanılan Kaynaklar}

Anonymous, 2012. T.C. Başbakanlık Türkiye İstatistik Kurumu Başkanlığı, Ankara. (Web sayfası: http://www.tuik.gov.tr.) (Erişim tarihi: Haziran, 2014).

Ay, R \& M. O. Gürkan, 2005. Resistance to bifenthrin and resistance mechanisms of different strains of the twospotted spider mite (Tetranychus urticae Koch) from Turkey. Phytoparasitica, 33: 237-244.

Ay, R \& F. E. Kara, 2011. Toxicity, inheritance and biochemistry of clofentezine resistance in Tetranychus urticae. Insect Science, 18(5): 503-511.

Bradford, M. M., 1976. A rapid and sensitiv method for the quantitation of microgramm quantities of protein utilizing the principle of protein - dye inding. Analytical Biochemistry, 72: 248-254.

Bretschneider, T., R. Fisher \& R. Nauen, 2007. "Inhibitors of lipid synthesis (acetyl-CoA- carboxylase inhibitors), 909925". In: Modern Crop Protection Compounds (Ed: W. Kramer \& U. Schirmer). Wiley, Weinheim, 1025p.

Dekeyser, M. A., 2005. Acaricide mode of action. Pest Management Science, 61: 103-110.

Demaeght, P., W. Dermauw, T. Tsakireli, J. Khajehali, R. Nauen, L. Tirry, J. Vontas, P. Lümmen, \& T. Van Leuween, 2013. Molecular analysis resistance to acaricidal spirocylic tetranic acids in Tetranychus urticae: CYP392E10 metobolizes spirodiclofen, but not its corresponding enol. Insect Biochemical Molecular Biology, 43: 544-554.

Goka, K \& A. Takafuji, 1992. Enzyme variations among Japanese populations of the two-spotted spider mites, Tetranychus urticae Koch. Applied Entomology Zoology, 27: 141-150.

Helle, W. \& M.W. Sabelis. 1985. Spider Mites: Their Biology, Natural Enemies and Control. Elsevier, Amsterdam, 545p.

Hu, J., C. Wang, J. Wang, Y. You \& F. Chen, 2010. Monitoring of resistance to spirodiclofen and five other acaricides in Panonychus citri collected from Chinese citrus orchards. Pest Management Science, 66: 1025-1030.

Jeppson, L. R., H. H. Keifer \& E. W. Baker, 1975. Mites Injurious to Economic Plants. University of California Press, Berkeley, $614 \mathrm{p}$.

Khajehali, J., P. Nieuwenhuyse, P. Demaeght, L. Tirry \& T. Van Leeuwen, 2011. Acaricide resistance and resistance mechanisms in Tetranychus urticae populations from rose greenhouses in the Netherlands. Pest Management Science, 67: 1424-1433.

Konanz, S. \& R. Nauen, 2004. Purification and partial characetrization of a glutathione s-transferase from the twospotted spider mite, Tetranychus urticae. Pesticide Biochemistry and Physiology, 79(2): 49-57. 
Isparta ili merkez ilçesinde domates seralarından toplanan Tetranychus urticae Koch (Acari: Tetranychidae) popülasyonlarının bazı akarisitlere karşı direnç düzeyleri ve detoksifikasyon enzimleri

Leeuwen, T. \& L. Tirry, 2007. Esterase-mediated bifenthrin resistance in a multiresistant strain of the two-spotted spider mite, Tetranychus urticae. Pest Management Science, 63:150-156.

LeOra Software, 1994. Polo-pc: a User' s Guide to Probit or Logit Analysis Leora Software, Berkeley, 28p.

Lin, H., X. Chuan-hua, W. Jin-jun, L. Ming, L. Wen-cai \& Z. Zhi-mo, 2009. Resistance selection and biochemical mechanism of resistance to two acaricides in Tetranychus cinnabarinus (Boiduval). Pesticide Biochemistry and Physiology, 93: 47-52.

Miresmailli, S. \& M. B. Isman, 2006. Efficacy and persistence of rosemary oil as an acaricide against two spotted spider mite (Acari: Tetranychidae) on greenhouse tomato. Journal of Economic Entomology, 99: $2015-2023$.

Moghadama, M. M., M. Ghadamyaria \& K. Talebi, 2012. Resistance mechanisms to fenazaquin in Iranian populations of two-spotted spider mite, Tetranychus urticae Koch (Acari: Tetranychidae). International Journal of Acarology, 38(2): 138-145.

Nauen, R., N. Stumpf \& A. Elbert, 2000. "Efficacy of BAJ 2740, a new acaricidal tetronic acid derivative, against tetranychid spider mite species resistant to conventional acaricides". Proceedings of the Brighton Crop Protection Conference. (14-18 Nowember 1990, UK), 829 p.

Pottelberge, S. V., T. V. Leeuwen, J. Khajeali \& L. Tirry, 2009. Genetic and biochemical analysis of a laboratoryselected spirodiclofen-resistant strain of Tetranychus urticae Koch (Acari:Tetranychidae). Pest Management Science, 65: 358-366.

Pree, D. J., L. A. Bittner \& K. J. Whitty, 2002. Characterization of resistance to clofentezine in populations of european red mite from orchards in Ontario. Experimental and Applied Acarology, 27: 181-193.

Putter, I., J. G. MacConnell, F. A. Presier, A. A. Haidri, S. S. Ristich \& R. A. Dybas, 1981. Avermectins: novel insecticides, acaricides and nematicides from a soil microorganism. Cellular Molecular Life Science, 37: 963-964.

Rauch, N. \& R. Nauen, 2003. Spirodiclofen resistance risk assessment in Tetranychus urticae (Acari: Tetranychidae): a biochemical approach. Pesticide Biochemistry and Physiology, 74: 91-101.

Reissig, W. H. \& L. A. Hull, 1991. Hexythiazox resistance in a field population of european red mite (Acari: Tetranychidae) on apples. Journal of Economic Entomology, 84(3): 727-735.

Rose, R. L., R. Barbhaiya, G. Rock \& E. Hodgson, 1995. Cytochrome P-450-associated insecticide resistance and the development of biochemical diagnostic assays in Heliothis virescens. Pesticide Biochemical Physiology, 51: 178-191.

Sanatgar, E., R. V. Shoushtari, A. A. Zamani, M. Arbabi \& E.S. Nejadian, 2011. Effect of frequent application of hexythiazox on predatory mite Phytoseiulus persimilis Athias - Henriot (Acari: Phytoseiidae). Acade Journal of Entomology, 4: 94-101.

Sato, M. E., M. Z. Silva, A. Raga \& M. F. S. Filho, 2005. Abamectin resistance in Tetranychus urticae Koch (Acari: Tetranychidae): selection, cross-resistance and stability of resistance. Neotropic Entomology, 34: 991-998.

Stumpf, N. \& R..Nauen, 2001. Cross-resistance, inheritance and biochemistry of mitochondrial electron transport inhibitor-acaricide resistance in Tetranychus urticae (Acari: Tetranychidae). Journal of Economic Entomololgy, 94(6): 1577-1583.

Stumpf, N. \& R. Nauen, 2002. Biochemical markers linked to abamaectin resistance in Tetranychus urticae (Acari: Tetranychidae). Pesticide Biochemical and Physiology, 72: 111-121.

Van Leeuwen, T., S. V. Pottelberge \& L. Tirry, 2005. Comparative acaricide susceptibility and detoxifying enzyme activities in field-collected resistant and susceptible strains of Tetranychus urticae. Pest Management Science 61: 499-507.

Van Leeuwen, T. V., L. Tirry, \& R. Nauen, 2006. Complete maternal inheritance of bfenazate resistance in Tetranychus urticae Koch (Acari: Tetranychidae) and its implications in mode of action considerations. Insect Biochemistry and Molecular Biology, 36: 869-877.

Van Leeuwen, T \& L. Tirry, 2007. Esterase-mediated bifenthrin resistance in a multiresistant strain of the two-spotted spider mite, Tetranychus urticae. Pest Mnagement Science, 63:150-156.

Wang, L \& Y. Wu, 2007. Cross-resistance and biochemical mechanisms of abamectin resistance in the B-type Bemisia tabaci. Journal of Applied Entomology, 131: 98-103. 
Winer, B. J., D. R. Brown \& K. M. Michels, 1991. Statistical Principles in Experimental Design, ISBN 0-07-070982-3, New York, 552p.

Yamamoto, A., H. Yoneda, R. Hatano \& M. Asada, 1996. Realized heritability estimates of hexythiazox resistance in the citrus red mite Panonychus citri (McGregor). Journal of Pesticide Science, 21: 43-47.

Yang, X., L. L.,Buschman, K. Y. Zhu \& D.C. Margolies, 2002. Susceptibility and detoxifying enzyme activity in two spider mite species (Acari: Tetranychidae) after selection with three Insecticides. Journal of Economic Entomology, 95(2): 399-406.

Yorulmaz, S. \& R. Ay, 2009. Multiple resistance, detoxifying enzyme activity, and inheritance of abamectin resistance in Tetranychus urticae Koch (Acarina: Tetranychidae). Turkish Journal of Agriculture and Forestry, 33: 393-402.

Yorulmaz, S., P. Kaplan, D. Boztürk, S. Çobanoğlu \& R. Ay, 2010. Isparta ili elma bahçelerinden toplanan Tetranychus urticae Koch. (Acarina: Tetranychidae) popülasyonlarının cyhexatin ve propargite karşı duyarlılıklarının belirlenmesi. Süleyman Demirel Üniversitesi Ziraat Fakültesi Dergisi, 5 (1): 17-23.

Zhang, Z., 2003. Mites of Greenhouses: Identification, Biology and Control. CABI Publishing, Wallingford, 828 p. 